\title{
Online Disclosure of University Environmental Responsibility: A Case of Indonesia
}

\author{
Alia Ariesanti ${ }^{1}$ \\ ${ }^{1}$ Universitas Ahmad Dahlan, Indonesia, e-mail: alia.ariesanti@act.uad.ac.id
}

\begin{abstract}
A university has a commitment to maintain transparency and accountability. To fulfill that obligation and win the high competition, the university strives to improve the brand image by disclosing positive information to public. Therefore, the university proposed environmental activities as a form of communication and responsibility to people through various media, one of which was using a website. This article aims to: first, to analyze whether the environmental activity used by a university was a competitive advantage which then disclosed information on their website; second, to analyze which indicator was the university's concern to be conveyed in their website. A study of Indonesian universities participating in the UI Green Metric 2017 showed that there were still a few universities that implemented environmental activities on their website. A study of Indonesian universities participating in the UI Green Metric 2017 showed that there were a few universities that disclosed their environmental activities on their website. Environmental disclosure was not being used as a differentiating factor in competitive advantage. In addition, the indicator that was widely disclosed was information about transportation.
\end{abstract}

Keywords: environmental responsibility; universities; online disclosure of information; sustainability

\section{Introduction}

Sustainable development is one of the crucial missions in the 21 st century (Weenen, 2000). The development carried out by various countries in the world has caused damage to the environment which then affects the quality of life of humans and other living things. Therefore, in 1987 the United Nations (UN) through the Bruntland Committee described the importance of sustainable development. Sustainable development is defined as:

"The ability to make development sustainable to ensure that it meets the needs of the present without compromising the ability of future generations to meet their own needs" (WCED, 1987)

This definition implies that the development carried out not only gains the maximum profit and increases the standard of living of a small number of people, but also be useful to improve the quality of life of all parties. In addition, the development carried out must not cause damage to nature, exploit excessive natural resources, and also result in pollution.

To support the achievement of sustainable development goals, the involvement of various parties is needed, one of which is a university. As a formal education institution, universities have an important role. Universities can provide knowledge, expertise and values to students and the community (UNESCO, 2014), then a sustainable life can be realized. Education is an important factor for initiating change in society (Idris, 2013; Unesco, 2005). This statement is also supported by the educational objectives that formulated by UNESCO (1997) below:

Education serves society in a variety of ways. The goal of education is to make people wiser, more knowledgeable, better informed, ethical, responsible, critical and capable of continuing to learn. Were all people to possess such abilities and qualities, the world's problems would not be automatically solved, but the means and the will to address them would be at hand. Education also serves society by providing a critical reflection on the world, especially its failings and injustices, and by promoting greater consciousness and awareness, exploring new visions and concepts, and inventing new techniques and tools. Education is also the means for disseminating knowledge and developing skills, for bringing about desired changes in behaviors, values and lifestyles, and for promoting public support for the continuing and fundamental changes that will be required if humanity is to alter its course, leaving the familiar path that is leading towards growing difficulties and possible catastrophe, 
and starting the uphill climb towards sustainability. Education, in short, is humanity's best hope and most effective means in the quest to achieve sustainable development. (Unesco, 1997)

The role of universities is realizing sustainable development goals through teaching, research and service activities by minimizing the negative impacts caused by environmental and social aspects. Another role is to educate people about the importance of preserving the environment and social welfare, so that it becomes a sustainable lifestyle (Arbuthnott, 2009).

Various efforts done by universities to implement the sustainable university concept need to be expressed in various information media. Universities are required to prepare annual reports published to the public. This statement is stated by Law Number 12 of 2012 concerning Article 78 of Higher Education about the accountability of higher education. This submission is a form of transparency and accountability for Higher Education (Indonesia, 2012).

The competition among universities is increasing because of the increasing number of universities in Indonesia. To win the competition, universities try to improve the image by conveying positive information to people, one of which is information about social and environmental aspects (Atakan \& Eker, 2007). In accordance with legitimacy theory, entities are more likely to express sustainability activities as a form of legitimacy to people. The entity tries to convince people that its operations are in line with the expectations and perceptions of the society (O'Donovan, 2002).

Previous research conducted on business companies shows that the disclosure of social and environmental responsibilities has an impact on stakeholder perceptions (Crowther \& Aras, 2008; Elsakit \& Worthington, 2012), increasing public reputation and image (Effiong, Akpan, \& Oti, 2012), and improving brand image (Tantawi, Passent; Youssef, 2008) to gain competitive advantage. By learning from business companies, it is known that disclosure of social and environmental responsibility can be an attractive option to prospective students.

In order to deliver the information to people effectively and efficiently, the university may use website media. Website is one of the communication media that must be owned by the university because it has great benefits. Nowadays, more and more potential prospective students are getting information and making decisions to choose universities based on university websites (Manzoor, Hussain, Ahmed, \& Iqbal, 2012; Schimmel, Motley, Marco, \& Eschenfelder, 2010). Websites play a key role to improve information transparency (Meijer 2009), improve communication, and enrich the type of information delivered to people (Djajadikerta \& Trireksani, 2012).

This article has two main objectives: firstly, to analyze whether in disclosing accountable and transparent information, and the effort to win the competition, the university considered the disclosure of environmental information as competitive advantage through their website; secondly, to analyze which indicators were important for universities to be used on their website.

Universities have a crucial role in sustainable development programs. Universities are the agents of change for social and political conditions in a country. This is because universities educate leaders, policy makers, educators, businesspeople, workers and others. Through universities, knowledge, values and norms can be spread to the community. Because the role of universities is very important, universities are required to be involved in solving environmental and social problems arising from development. Universities are expected to bring about sustainable development innovations through various activities carried out in universities.

The implementation of every activity in universities is regulated in Law No. 60 of 1999. According to the regulation, the purpose of university is to prepare students to become knowledgeable members of the community, and to develop and disseminate their knowledge to improve the life quality of the community. Based on these regulations, universities can support sustainable development programs by providing knowledge through the teaching process, which can be the best solution to face the challenges of social welfare, economic justice and environmental sustainability through the formation of mentality and behavior of academicians (Al-khateeb, Al-ansari, \& Knutsson, 2014; Arbuthnott, 2009). 
Universities also conduct research and community service, in addition to carrying out teaching functions. The task of teaching, research and community service needs to be supported by administrative activities and other operational activities. Research activities and community service as well as university operational activities must also consider environmental sustainability, social welfare and economic justice.

The important role of universities in supporting sustainable development triggers the concept of the sustainable university. The concept developed by the World Summit on Sustainable Development in Johannesburg in 2002. The forum initiated by the United Nations (UN) considered that education is an important factor to support sustainable development. The results of the discussion formulated the Decade of Education for Sustainable Development which stated that in 2005 to 2014, the countries of UN member led by UNESCO (United Nations Educational, Scientific and Cultural Organization) would support sustainable development through education.

Sustainable university is a program aimed at universities so that their teaching, research and community service activities consider the economic, environmental and social aspects and minimize the negative impact of resource use and support the realization of a sustainable community lifestyle. The concept of sustainable university emphasizes the importance of economic, environmental and social aspects in every activity carried out by universities, starting from the preparation of the vision, mission, and strategies of universities to the reports compiled by universities (Velazquez, Munguia, Platt, \& Taddei, 2006). Moreover, sustainable university also prepares students to be able to contribute to environmental sustainability and social welfare (Arbuthnott, 2009). When they become students, they are required to play an active role in supporting social university programs, and when they graduate, they are required to share knowledge about environmental sustainability and social welfare to other people.

Every activity carried out by universities is directed to maintain the environmental sustainability and social welfare, while also maintaining the survival of universities from an economic standpoint, so that the tertiary institutions can continue to operate. The sustainability actions taken by the university can minimize the adverse effects of operating activities on the environment so that the natural resources can be utilized as efficiently as possible. The actions can also educate people about sustainability. Therefore, a good natural environment may continue to be enjoyed by future generations.

Currently, the number of universities in Indonesia which under the coordination of the Ministry of Research, Technology and Higher Education reaches 3,250, consisting of 122 state universities (3.75\%) and 3,128 private universities (96.25\%) (forlap.ristekdikti, 2018). For state universities, the government issues regulations that require state universities to prepare financial report to ensure public transparency and accountability. The report is a form of accountability for the use of funds sourced from the state budget, the community and other sources. The form and report period of the tertiary institution are different, depending on the status of the relevant state university.

For state university, according to its financial management, is divided into two, namely Public Service Bodies (BLU) and State-Owned Legal Entities (BHMN). The financial report for BLU universities is regulated by the Minister of Finance Regulation Number 76 of 2008, while for BHMN universities, it is regulated by the Minister of Finance Regulation Number 225 of 2014. Basically, the two regulations require state university to prepare financial statements/ reports and performance reports which are guided by the Standard Financial Accounting and Government Accounting Standards.

The regulation on the preparation of financial statements is applied only for state universities, while for private universities, there are no rules that require them to compile financial reports. The preparation of financial report for private university is still limited to internal interests, namely as the accountability to the owner or foundation of the university. Private tertiary institutions, whose funding sources are mostly even from public funds, should be obliged to prepare financial reports as a form of accountability to the public and a form of transparency because they use funds from public. 
Universities, both those with state and private status, are obliged to prepare reports for accreditation purposes. The rules for universities to compile accreditation reports are regulated in the Republic of Indonesia Law Number 20 of 2003 about the National Education System. The accreditation report is a form of accountability to people regarding the implementation of programs and/or education units in a university that is carried out objectively, fairly, transparently and comprehensively (BAN, 2015). The feasibility of a program and/or education unit needs to be assessed because it determines the quality of education outcomes. The government gives the authority to the National Higher Education Accreditation Board to assess the feasibility of a program and/or education unit.

Based on research, the reports of universities in Indonesia is still limited to financial reports and activity reports, then no one has published a sustainability report that stands alone. Sustainability information disclosed by universities can be obtained from financial reports, which are reported to the Ministry of Finance, as well as reports for accreditation purposes, which are reported to the Ministry of Higher Education.

Reports compiled by universities, both reported to the Ministry of Higher Education and to the Ministry of Finance, have not been able to disclose sufficient information about the sustainability activities carried out by universities (Musyarofah, 2012). Musyarofah (2012) conducted research in a state university. The results of the research show that sustainability information presented in LAKIP (Accountability Report on Performance of Government Agencies) is still far from the scope of sustainability report so that it cannot be used to assess the sustainability activities of universities. Likewise, for the report for the purpose of accreditation, it cannot be used to assess the sustainability activities of universities.

Although there has been no requirement to disclose information on social and environmental activities, universities may disclose this information through various alternatives of media, one of which is through the website. There are several reasons the website was chosen as an alternative media to disclose voluntary information. The website can be an interactive media and the reach of the internet is increasingly widespread in the community. In addition, websites are relatively inexpensive media and they are media formats (hyperlinks, voice or video) that are more flexible than disclosures in the form of printed reports (Amran, 2012; Djajadikerta \& Trireksani, 2012).

\section{Research Methodology}

The objects of this study were the universities in Indonesia which participate in the University of Indonesia (UI) Green Metric Program. As many as 57 university websites were examined to obtain the data, then the data were analyzed to answer the research problems. The selection of universities in this study did have limitation because the only conditions were that the universities participated in the UI Green Metric program and disclosed the information through the website. This study did not address universities that were committed to sustainability matter but did not disclose their commitments or disclose such information in different ways, for example printed materials (posters, brochures, magazines, etc.).

UI Green Metric participants were chosen as the objects of this research with the consideration that UI Green Metric had clear assessment indicators, making it easier for participants to provide information needed for the assessment process. In addition, one of the components of the Green Metric UI assessment was universities had their own websites that contained information related to sustainability activities conducted by universities. Therefore, the objects of this research which were the universities that took part in the Green Metric program were the right choice because it was expected that the universities had their own websites, and more information was related to the sustainability activities revealed on the website.

From August to September 2018, the researcher visited the websites of the selected universities in order to obtain information necessary for this study. Content analysis was conducted to collect information about the social and environmental activities that were disclosed through the website. Content analysis is a method that is often done to measure broad disclosures of social and 
environmental activities (Aribi \& Gao, 2010; Djajadikerta \& Trireksani, 2012; Guthrie \& Abeysekera, 2006). Content analysis is a flexible analysis tool, which can be used to analyze quantitative data, qualitative data and mixed methods (White \& Marsh, 2006). For the formulation of the initial category, indicators were used according to Green metric UI. They were setting and infrastructure, climate change and energy, waste, water, transportation and education. To ensure the objectivity, the process was carried out by each of the authors, who subsequently discussed the results and reached a consensus. If there were any significant discrepancies, the websites were examined again by the authors.

The unit of analysis used in this study was the number of words. The consideration of the word as a unit of analysis was because it could be complete, reliable and meaningful data for subsequent analysis (Milne \& Adler, 1999). In addition to words, this research also considered the images which presented on the website. It was because images could also provide information about the sustainability activities carried out by the universities. Images can also be an analytical unit in collecting data using content analysis because images can represent many words (Guthrie \& Abeysekera, 2006).

\section{Result and Discussion}

The participants of UI Green Metric were mostly state universities, which were 41 universities. It means that $33.6 \%$ of the total state universities have participated in UI Green Metric program, whereas only 16 private university participated in this program or only $0.5 \%$ of the total private universities in Indonesia.

From the 57 universities that became the objects of observation of this study, 17 of them had special websites for disclosure of environmental responsibilities. It means that only around $29.8 \%$ of universities were willing to disclose their environmental activities through a special website. A special website to reveal environmental activities was one of the Green Metric UI assessment components in the education indicator with a total weight of $18 \%$.

The result of the observations on the university special website, eight websites were well-managed, and the information was up-to-date. In addition, almost all indicators were disclosed on the website. The website was equipped with pictures and photos of activities, which helped the reader to obtain more information about the environmental activities carried out by universities.

While nine other college websites did not update the information on the website for the past 1 year. The information disclosed on the website was an activity that was carried out more than one year ago. Even more, there were websites that did not disclose any information.

From the 57 universities that participated in the UI Green Metric program, at most 12 universities revealed information about sustainability activities carried out through the website (Table 1). It means that only $21 \%$ of universities were willing to disclose their environmental activities. Most universities disclosed the setting and infrastructure indicators, which were 12 universities. While the indicator that was the least disclosed was water, which was disclosed by 7 universities. 
Table 1. The disclosure of indicators

\begin{tabular}{|l|c|l|l|l|}
\hline \multicolumn{1}{|c|}{ Indicators } & $\begin{array}{c}\text { Number of } \\
\text { universities disclosing } \\
\text { the indicators }\end{array}$ & $\begin{array}{c}\text { Number } \\
\text { of words }\end{array}$ & Average & Description \\
\hline $\begin{array}{l}\text { Setting and } \\
\text { Infrastructure (SI) }\end{array}$ & 12 & 2207 & 184 & UII (448) \\
\hline $\begin{array}{l}\text { Energy and Climate } \\
\text { Change (EC) }\end{array}$ & 8 & 2847 & 356 & UI (1599) \\
\hline Waste (WS) & 9 & 2472 & 275 & UI (1166) \\
\hline Water (WR) & 7 & 1420 & 203 & UI (505) \\
\hline Transportation (TR) & 8 & 2911 & 364 & IPB (1404) \\
\hline Education (ED) & 8 & 1996 & 250 & $\begin{array}{l}\text { UNS (533) } \\
\text { Telkom (611) }\end{array}$ \\
\hline
\end{tabular}

For the number of words disclosed (table 1), the transportation indicator was expressed by the highest number of words compared to other indicators, which reached a total of 2,911 words. On the average, the universities which revealed transportation indicators used 364 words.

The university which used the highest number of words for disclosing the setting and infrastructure indicator was the Indonesian Islamic University with 448 words. For the indicators of energy and climate change, the highest number of words was expressed by the University of Indonesia with a total of 1,599 words. The highest number of words of disclosing waste indicator was reached by the University of Indonesia with 1,166 words. The highest number of words of disclosing the water indicator was reached by the University of Indonesia with 505 words. The highest number of words for disclosing the transportation indicator was reached by Bogor Agricultural University, 1,404 words. For the education indicator, the assessment criteria in this study were expanded with the efforts made by university to raise awareness of the academic community, especially students about the environment. Therefore, if there was a university that disclosed information related to the involvement of academics and / or students in environmental activities, the number of words used to disclose the information was still considered. In the education indicator, with the criteria according to UI Green Metric, Sebelas Maret University revealed the most information, which reached 533 words. Whereas when using the developed criteria, Telkom University revealed the most information, which reached 611 words.

Table 2 The 5 universities with the highest disclosure of the environmental information

\begin{tabular}{|l|l|r|r|r|r|r|r|c|}
\hline No & University & SI & EC & WS & WR & \multicolumn{1}{l|}{ TR } & ED & Total \\
\hline 1 & UI & 191 & 1599 & 1166 & 505 & 317 & & 3778 \\
\hline 2 & UNS & 266 & 372 & 322 & 355 & 513 & 533 & 2361 \\
\hline 3 & IPB & 336 & 59 & 78 & & 1404 & 159 & 2036 \\
\hline 4 & Telkom & 181 & 197 & 337 & 62 & 163 & 611 & 1551 \\
\hline 5 & USU & 161 & 314 & 225 & 335 & 312 & 169 & 1516 \\
\hline
\end{tabular}

Table 2 presents the information about the 5 universities with highest environmental disclosure. The table shows that University of Indonesia (UI) is the university which had the highest disclosure of environmental information through the website, with the highest indicator is energy and climate change. For the indicator of education, UI did not disclose any information. UI website also disclosed information about the results of assessing environmental activities for each faculty of UI.

Sebelas Maret University (UNS) is ranked second. The highest indicator revealed was education. UNS revealed complete and detailed education information in accordance with the provisions of the 
UI Green Metric, including the number of courses offered, the amount of research and the amount of funds, the number of publications and scientific activities, the number of student activity units, and the existence of websites related to sustainability.

Bogor Agricultural Institute (IPB) ranks third. The highest indicator revealed was transportation. Information about transportation indicator was widely disclosed by this university. It was the information about environmentally friendly transportation policies. To complete this transportation information, the website was equipped with parking maps, location plans and photographs of electric cars. This university did not disclose information about the water indicator.

The fourth place is occupied by Telkom University. Telkom revealed the most information in the education indicator, while the lowest disclosure was on the water indicator. Telkom University website was equipped with photos of activities carried out related to the environment, to add information in the form of words.

The fifth place is occupied by the University of North Sumatra (USU), with the highest disclosure on the water indicator. The lowest disclosure was in the setting and infrastructure indicator. USU's sustainability website did not display many photos. Much information was given in words, according to the assessment component for each indicator.

Based on the number of universities which participated in the UI Green Metric program, the participants of this environmental program were still low. Although the number of participants from Indonesia is increasing every year, the number of universities which participated in the environmental program were only 57 universities of the total universities in Indonesia amounting to 3,250 (or only $1.8 \%$ ). In addition, the number of universities that made their own websites for disclosure of environmental activities was only 17 universities.

Universities in Indonesia do not consider the sustainability aspect to be the important information, which may improve reputation and image so that it has not been disclosed on the website. In fact, information about social and environmental activities conveyed to stakeholders has an impact on the image of the university (Plungpongpan, Tiangsoongnern, \& Speece, 2016), which can increase stakeholders' trust. Brand image needs to be built by university because (1) it can attract the attention of prospective students and their parents; (2) it can increase the ability to recruit human resources; (3) it is as a differentiator from competing universities, and (4) it gains market share (Bennett \& AliChoudhury, 2009).

To fulfill the obligations to stakeholders, that are accountability and transparency, university chooses to use various communication channels. Website media is an alternative form of communication with stakeholders which is easy and inexpensive (Manzoor et al., 2012). More stakeholders of the university seek information online, because it is easy and practical. Online network users are mainly 16-24 years old (Plungpongpan et al., 2016), which are the "potential customer" for university. Hence, university should be able to use the website media as well as possible to attract the attention of stakeholders, especially prospective students and their parents by increasing brand image through disclosure of social and environmental activities.

The results of this study are similar to the research conducted by Tetřevová \& Sabolová (2010) which conducted in Chezh and Djajadikerta \& Trireksani (2012) which conducted in Indonesia. The results are (1) the university website had not been used effectively to disclose information related to social environment to stakeholders, (2) environmental information was not easily found on the university's website.

To increase the university awareness to disclose environmental information, the pressure from relevant stakeholders is needed. For example, university leaders adopt reporting standards and highlight the benefits of sustainability reporting (Alonso-Almeida, Marimon, Casani, \& RodriguezPomeda, 2015). 


\section{Conclusion}

Universities in Indonesia that participated in the UI Green Metric program were 57 universities, consisting of 41 state universities (72\%), and 16 private universities $(28 \%)$. From the 57 universities, it was analyzed that only 17 universities had special websites to disclose environmental activities carried out. Not all of the websites were managed properly because some websites contained information in the form of words or images that had not been updated in the past year. It shows that universities in Indonesia still considered that activities related to the environment carried out had not become necessary information or considered important to be disclosed and conveyed to the public through the website.

From the assessment aspect set in the UI Green Metric, 12 universities revealed indicators of setting and infrastructure. The indicator was most widely disclosed by university compared to other indicators, although the number of words used to express the indicator was the lowest. Whereas the most disclosed indicator was transportation.

\section{References}

Al-khateeb, M. A., Al-ansari, N., \& Knutsson, S. (2014). Sustainable University Model for Higher Education Iraq. Creative Education, 5, 318-328.

Alonso-Almeida, M. D. M., Marimon, F., Casani, F., \& Rodriguez-Pomeda, J. (2015). Diffusion of sustainability reporting in universities: Current situation and future perspectives. Journal of Cleaner Production, 106, 144-154. https://doi.org/10.1016/j.jclepro.2014.02.008

Amran, A. (2012). Exploring Online Sustainability Disclosure among Malaysian company. Procedia - Social and Behavioral Sciences, 65, 761-767.

Arbuthnott, K. D. (2009). Education for Sustainable Development Beyond Attitude Change. International Journal of Sustainability in Higher Education, 10(2), 152-163.

Aribi, Z. A., \& Gao, S. (2010). Corporate social responsibility disclosure. Journal of Financial Reporting and Accounting, 8(2), 72-91. https://doi.org/10.1108/19852511011088352

Atakan, M. G. S., \& Eker, T. (2007). Corporate Identity of a Socially Responsible University-A Case from the Turkish Higher Education Sector. Journal of Business Ethics, 76, 55-68.

BAN. (2015). Rasionalisasi Akreditasi. Retrieved September 27, 2015, from http://banpt.kemdiknas.go.id/rasional

Bennett, R., \& Ali-Choudhury, R. (2009). Prospective students' perceptions of university brands: An empirical study. Journal of Marketing for Higher Education, 19(1), 85-107. https://doi.org/10.1080/08841240902905445

Crowther, D., \& Aras, G. (2008). Corporate Social Responsibility (First). bookboon.com.

Djajadikerta, H. G., \& Trireksani, T. (2012). Corporate social and environmental disclosure by Indonesian listed companies on their corporate web sites. Journal of Applied Accounting Research, 13(1), 21-36. Retrieved from http://www.emeraldinsight.com/10.1108/09675421211231899

Effiong, S. A., Akpan, E. I., \& Oti, P. A. (2012). Corporate Governance, Wealth Creation and Social Responsibility Accounting. Management Science and Engineering, 6(4), 110-114.

Elsakit, O. M., \& Worthington, A. C. (2012). The Attitudes of Managers and Stakeholders towards Corporate Social and Environmental Disclosure. International Journal of Economics and Finance, 4(12), 240-252. https://doi.org/10.5539/ijef.v4n12p240

Guthrie, J., \& Abeysekera, I. (2006). Content analysis of social, environmental reporting: what is new? Journal of Human Resource Costing \&amp; Accounting, 10(2), 114-126. https://doi.org/10.1108/14013380610703120

https://forlap.dikti.go.id. 2018.

Idris, R. (2013). Pendidikan Sebagai Agen Perubahan Menuju Masyarakat Indonesia Seutuhnya (Education as an Agent of Change Towards a Complete Indonesian Society). Lentera Pendidikan, 16(1), 62-72. 
Indonesia, G. of. Acts no. 12 of 2012 on Higher Education (2012). Indonesia.

Manzoor, M., Hussain, W., Ahmed, A., \& Iqbal, M. J. (2012). The Importance Of Higher Education Website And Its Usability. International Journal of Basic and Applied Sciences, 1(2), 150-163. https://doi.org/10.14419/ijbas.v1i2.73

Milne, M. J., \& Adler, R. W. (1999). Exploring the reliability of social and environmental disclosures content analysis. Accounting, Auditing \& Accountability Journal, 12(2), 237-256.

Musyarofah, S. (2012). Akuntabilitas Pendidikan Tinggi Melalui Sustainability Reporting. Disertasi Universitas Brawijaya Malang.

O'Donovan, G. (2002). Environmental disclosures in the annual report. Accounting, Auditing \& Accountability Journal, 15(3), 344-371. https://doi.org/10.1108/09513570210435870

Plungpongpan, J., Tiangsoongnern, L., \& Speece, M. (2016). University social responsibility and brand image of private universities in Bangkok. International Journal of Educational Management, 30(4), 63-83. https://doi.org/http://dhttp://dx.doi.org/10.1108/IJEM-10-20140136

Schimmel, K., Motley, D., Marco, G., \& Eschenfelder, M. (2010). The Importance Of University Web Pages In Selecting A Higher Education Institution. Research in Higher Education Journal, 9(1), 1-16.

Tantawi, Passent; Youssef, A. (2008). The Importance of Corporate Social Performance in Place Branding of Retail Banks in Egypt.

Tetřevová, L., \& Sabolová, V. (2010). University stakeholder management and university social responsibility. WSEAS Transactions on Advances in Engineering Education, 7(7), 224-233.

Unesco. (1997). Educating for a Sustainable Future: a Transdisciplinary, (November). https://doi.org/UNESCO: EPD-97/CONF.401/CLD.1

Unesco. (2005). UN Decade of Education for The DESD at a glance. Retrieved from http://unesdoc.unesco.org/images/0014/001416/141629e.pdf

UNESCO. (2014). Roadmap Education for Sustainable Development. Unesco.

Velazquez, L., Munguia, N., Platt, A., \& Taddei, J. (2006). Sustainable University: What Can Be the Matter? Journal of Cleaner Production, 1-10.

WCED. (1987). Report of the World Commission on Environment and Development: Our Common Future (The Brundtland Report) (Vol. 4). Oxford.

Weenen, H. Van. (2000). Towards a Vision of a Sustainable University. International Journal of Sustainability in Higher Education, 1(1), 20-34.

White, M. D., \& Marsh, E. E. (2006). Content Analysis: A Flexible Methodology. Library Trends, 55(1), 22-45. https://doi.org/10.1353/lib.2006.0053 